Nig. J. Biotech. Vol. 33 (2017) 66-71

ISSN: 01891731

Available online at

http://www.ajol.info/index.php/njb/index

and www.biotechsocietynigeria.org

DOI: https://dx.doi.org/10.4314/v33i1.9

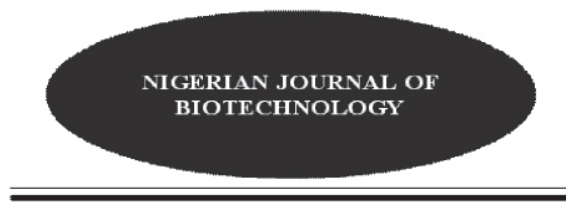

\title{
Optimization of biodiesel production from castor oil by response surface methodology
}

\author{
Garba, A. ${ }^{1}$, Abarshi, M. M. ${ }^{1}$, Shuaib, M. B. ${ }^{1}$ and Sulaiman, R. $^{2}$ \\ ${ }^{1}$ Department of Biochemistry, Ahmadu Bello University, Zaria, Nigeria. \\ ${ }^{2}$ Department of Biochemistry, Usman Danfodiyo University, Sokoto, Nigeria. \\ (Received: 18:05:2017; Accepted:23 :08:2017)
}

Copyright resides with the authors in terms of the Creative Commons License 4.0.
See http://creativecommons.org/licenses/by/4.0/
Condition of use: The user may copy, distribute, transmit and adapt the work, but must recognize the
authors and the Nigerian Journal of Biotechnology

\section{Abstract}

This work investigated the possibility of using response surface methodology based on a four factor five level central composite design to optimize biodiesel production from castor oil. The reaction variables were oil: ethanol ratio, lipozyme concentration, time and temperature. The properties of the biodiesel produced were assessed. The linear coefficient of lipozyme concentration (B), temperature (D), the quadratic coefficient of lipozyme concentration ( $B^{2}$ ), time $\left(C^{2}\right)$, temperature $\left(D^{2}\right)$, the interaction of oil/ethanol ratio and lipozyme concentration $(A * B)$, the interaction of lipozyme concentration and time $(B * C)$ had significant effect on the biodiesel yield $(p<0.05)$.The other variableswere not significant $(p>0.05)$.The specific gravity was $(0.91)$, refractive index $(1.41 \pm 0.01)$, viscosity $(14.1)$, cetane number $(53.9)$, calorific value (38.0 \pm $0.10)$, flash point $\left(150^{\circ} \mathrm{C}\right)$, cloud point $\left(7^{\circ} \mathrm{C}\right)$ iodine value $(101 \pm 0.53)$, acid value $(0.57 \pm 0.01)$, and saponification value $(180 \pm 0.25)$. Maximum yield was found to be $93.0 \%$ under the conditions of oil: ethanol ratio of (1:7.14), lipozyme concentration (40 U), time (165 min) and temperature $50^{\circ} \mathrm{C}$. The properties of the biodiesel produced were largely in conformity with ASTM D6751 standards.

Keywords: Biodiesel, castor oil, optimization, transesterification

Correspondence: garbaauwalu2011@gmail.com

\section{Introduction}

The rapid depletion of world's petroleum reserves and increased ecological concerns have prompted the demand of environment friendly renewable energy resources (Ashish et al., 2010). The development of alternative energy source to extend the fossil fuels has received a large interest in the last few decades due to an increasing concern to protect the environment and conserve the nonrenewable natural energy resources (Vicente et al., 1998).

A number of processes such as chemical, enzymatic and supercritical alcohol treatment have been employed for biodiesel production (Warabi et al., 2004). Transesterification reaction consists of reversible reactions between alcohol and triacylglycerol present in oil or fats to produce three moles of fatty acid alkyl esters and glycerol as a coproduct (Abdullahi et al., 2009). The use of non-edible oils such as karanja, polanga, jatropha, and castor oil have attracted great attention as they do not pose threats to food security when used as feedstock in fuel industry (Koh and Mohd, 2011).

Several parameters, such as the type of catalyst, alcohol/ oil molar ratio, temperature, purity of the reactants and free fatty acid content have a greater influence on the transesterification reaction (Giovanilton et al., 2011).

This study's main objective was to develop an approach for better understanding the relationships between the variables (factors) and the response ethyl ester formation to obtain the optimum conditionsthat will improve the biodiesel yieldusing response surface methodology (RSM).

\section{Materials and methods}

Collection of castor seed

The castor seeds were collected from SabonGari Market Kaduna State Nigeria and were ground into powdered form by using a simple grinder machine. 


\section{Oil extraction}

The castor oil was extracted using soxhlet extractor. About $500 \mathrm{ml}$ of $n$-hexane was poured in a round bottom flask and $100 \mathrm{~g}$ of ground castor seed packed in a filter paper was placed in the thimble according to AOAC (2000) with modification.

\section{Transesterification reaction}

Transesterification reaction was carried out in screw-capped vials placed inside a reciprocal shaker. The initial reaction mixture consisted of castor oil: ethanol molar ratio of 1:7.14 lipozyme (40 $\mathrm{U}$ ) immobilized from Mucormiehei and was stirred at 200 $\mathrm{rpm}$ along with the respective controls according to Kumari et al. (2009)

\section{Design of Experiments}

Central composite design integrated in response surface methodology (RSM) provided in the Design-Expert 7.1.4 (Stat-Ease, Inc) was employed to design the experiments and fit a quadratic response surface to the experimental data (Chin et al., 2009). The response $Y$, was the yield of biodiesel. The factors chosen were oil: ethanol ratio (A), lipozyme concentration (B), reaction time (C) and temperature (D). The impeller speed was fixed at $200 \mathrm{rpm}$. The yield) was fitted to a second-order model in order to correlate the response variable with the independent variable

\section{Analysis of the reaction products \\ The percentage conversion (\%) of ethyl ester was measured by determining the remaining unreacted fatty acid in the reaction mixture by titration with $\mathrm{NaOH}(0.1 \mathrm{M})$. The percentage conversion (\%) of ethyl ester was calculated using the formula below.}

Conversionofmethylester $(\%)=$

$\frac{\text { Vol.of NaOHusedwithoutenzyme - Vol. of NaOHusedwithenzyme }}{\text { Vol.ofNaOHusedwithoutenzyme }} \times 100$

\section{Characterization of the biodiesel produced}

The fatty acid ethyl ester was characterized for specific gravity using specific gravity bottle, viscosity was determined using viscometer (NDJ-5A) model, refractive index using Abbe's refractometer (Model AR-001). The cetane number of the produced biodiesel was determined according to Krisnangkura(1989). Calorific value was measured according to the method of Gerpen (2005), Flash point was determined according to ASTM D 93 (2000). The cloud points was determined according to ASTM D2500 (2000). Acid value, iodine and saponification number were determined by titrimetric method according to AOAC (2000).

\section{Results}

The highest biodiesel yield of $93.0 \%$ and $75.53 \%$ was obtained for experimental and predicted responses respectively in run 18 . The lowest response of $5.0 \%$ was recorded at run 23 with the predicted being $10.78 \%$ (Table). The final model equation in terms of actual factors is given in equation 1 :

Sqrt(Yield) $=-41.35648+109.52257 \times$

Oil/EOH +1.68536x lipozyme+0.14607x

Time +2.79340 x Temperature +297.52604x

Oil/EOH2-0.011360xLipozyme2-

4.746566E-004×Time2-0.030278 ×

Temperature2-2.16146 $\times \mathrm{Oil} / \mathrm{EOH} \times$ Lipozyme-0.40162*Oil/EOH $\times$ Time + $0.66875 *$ Oil/EOH $\times$ Temperature-

2.11574E-003 xLipozymexTime-

3.60833E-003 $\times$ Lipozyme $\times$ Temperature+

7.46296E-004 ×Time $\times$ Temperature

The results of the analysis of variance shows that the model F-value of 13.01 with $p$-value of $<$ 0.0001. The terms $B, C, B^{2}, C^{2}, D, D^{2}, A B$ and $B C$ were significant model terms by having "prob $>\mathrm{F}^{\prime}$ less than 0.050 . While $A, A^{2} A C, A D, B D$ and $C D$ were not significant model terms by having $p$-values greater than 0.050 . The $\mathrm{R} 2$ value was 0.92 (Table 2 ) 
Table 1: Experimental and predicted responses for central composite second-order design

\begin{tabular}{lllllll}
\hline $\begin{array}{l}\text { Run } \\
\text { order }\end{array}$ & $\begin{array}{l}\text { Oil/ethanol } \\
\text { ratio }\end{array}$ & $\begin{array}{l}\text { Lipozyme } \\
(\mathrm{U} / \mathrm{ml})\end{array}$ & $\begin{array}{l}\text { Time } \\
\text { (minutes) }\end{array}$ & $\begin{array}{l}\text { Temperature } \\
\left({ }^{\circ} \mathrm{C}\right)\end{array}$ & $\begin{array}{l}\text { Predicted } \\
\text { yield }(\%)\end{array}$ & $\begin{array}{l}\text { Actual yield } \\
(\%)\end{array}$ \\
\hline 1 & 0.02 & 10.00 & 30.00 & 25.00 & 32.02 & 38.00 \\
2 & 0.10 & 10.00 & 30.00 & 25.00 & 42.28 & 34.80 \\
3 & 0.02 & 70.00 & 30.00 & 25.00 & 77.60 & 70.00 \\
4 & 0.10 & 70.00 & 30.00 & 25.00 & 77.49 & 81.60 \\
5 & 0.02 & 10.00 & 300.00 & 25.00 & 26.33 & 20.60 \\
6 & 0.10 & 10.00 & 300.00 & 25.00 & 27.92 & 32.50 \\
7 & 0.02 & 70.00 & 300.00 & 25.00 & 37.64 & 52.30 \\
8 & 0.10 & 70.00 & 300.00 & 25.00 & 28.85 & 20.10 \\
9 & 0.02 & 10.00 & 30.00 & 75.00 & 20.28 & 16.70 \\
10 & 0.10 & 10.00 & 30.00 & 75.00 & 33.22 & 19.10 \\
11 & 0.02 & 70.00 & 30.00 & 75.00 & 55.04 & 51.00 \\
12 & 0.10 & 70.00 & 30.00 & 75.00 & 57.60 & 51.00 \\
13 & 0.02 & 10.00 & 300.00 & 75.00 & 24.67 & 21.10 \\
14 & 0.10 & 10.00 & 300.00 & 75.00 & 28.93 & 24.20 \\
15 & 0.07 & 70.00 & 300.00 & 75.00 & 25.15 & 20.30 \\
16 & 0.10 & 70.00 & 300.00 & 75.00 & 13.16 & 13.60 \\
17 & 0.02 & 40.00 & 165.00 & 50.00 & 19.04 & 74.00 \\
18 & 0.14 & 40.00 & 165.00 & 50.00 & 75.53 & 93.00 \\
19 & 0.06 & 20.00 & 165.00 & 50.00 & 16.96 & 25.40 \\
20 & 0.06 & 100.00 & 165.00 & 50.00 & 52.65 & 56.00 \\
21 & 0.06 & 40.00 & 105.00 & 50.00 & 63.23 & 74.00 \\
22 & 0.06 & 40.00 & 435.00 & 50.00 & 18.98 & 20.00 \\
23 & 0.06 & 40.00 & 165.00 & 75.00 & 10.78 & 5.00 \\
24 & 0.06 & 40.00 & 165.00 & 100.00 & 10.77 & 6.80 \\
25 & 0.06 & 40.00 & 165.00 & 50.00 & 75.70 & 76.20 \\
26 & 0.06 & 40.00 & 165.00 & 50.00 & 75.70 & 76.00 \\
27 & 0.06 & 40.00 & 165.00 & 50.00 & 75.70 & 76.00 \\
28 & 0.06 & 40.00 & 165.00 & 50.00 & 75.70 & 77.00 \\
29 & 0.06 & 40.00 & 165.00 & 50.00 & 75.70 & 70.00 \\
30 & 0.06 & 40.00 & 165.00 & 50.00 & 75.70 & 79.00 \\
\hline
\end{tabular}

Table 2: Analysis of variance of the quadratic model developed in the design of experiments

\begin{tabular}{ccccc}
\hline Parameters & Sum of Squares & Mean of Square & F- value & Prob $>\mathrm{F}$ \\
& \multicolumn{4}{c}{} \\
\hline Source model & 19901.54 & 1421.54 & 13.01 & $<0.0001$ \\
A & 25.83 & 25.83 & 0.24 & 0.6338 \\
B & 1909.95 & 1909.95 & 17.4 & 0.0008 \\
C & 2937.09 & 2937.09 & 26.88 & 0.0001 \\
D & 696.60 & 696.60 & 6.37 & 0.0233 \\
$A^{2}$ & 6.22 & 6.22 & 0.057 & 0.08147 \\
D $^{2}$ & 2867.09 & 2867.09 & 26.24 & 0.0001 \\
$C^{2}$ & 2051.78 & 2051.78 & 18.78 & 0.0006 \\
D & 9822.62 & 9822.62 & 89.89 & 0.0001 \\
AB & 107.64 & 107.64 & 0.99 & 0.03367 \\
AC & 75.26 & 75.26 & 0.69 & 0.4196 \\
AD & 7.16 & 7.16 & 0.065 & 0.8015 \\
BC & 1174.78 & 1174.78 & 10.75 & 0.0015 \\
BD & 117.18 & 117.18 & 1.07 & 0.3168 \\
\hline
\end{tabular}


Figure 1 shows the 3D plot for the interaction of oil: ethanol ratio and lipozyme concentration on biodiesel yield. The lower and higher levels of lipozyme did not result in higher yield of biodiesel, but maximum biodiesel yield was obtained at optimum lipozyme concentration. Figure 1 (b) shows that the biodiesel yield increased with increase in oil: ethanol ratio. The yield decreased with increase in the incubation time. Figure 1 (c) shows the 3D plot for the interaction of oil: ethanol ratio and temperature. The yield increased with the increase in oil: ethanol ratio. Figure 1 (d) shows that at lower and higher levels of lipozyme concentration the biodiesel yield did not increase. However at optimum lipozyme concentration, a maximum biodiesel yield was obtained. Figure 1(e) shows that at lower and higher

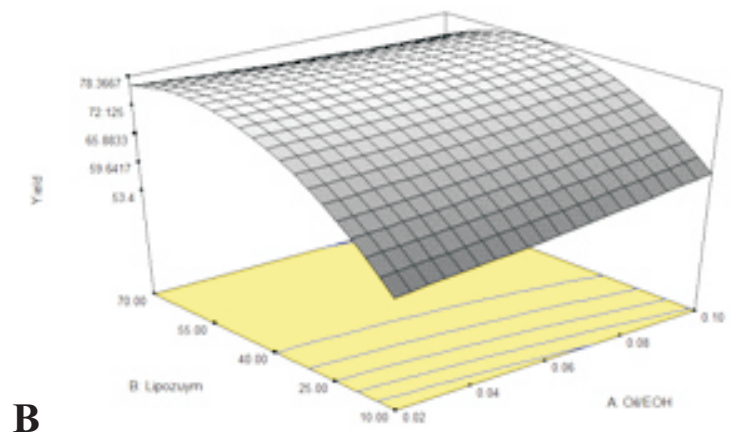

C

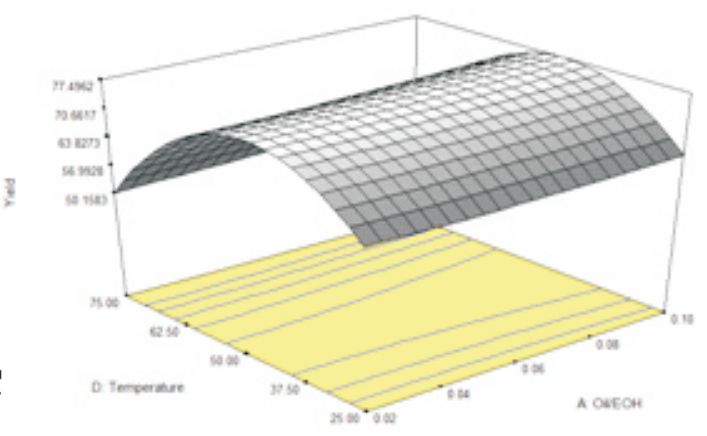

$\mathbf{E}$

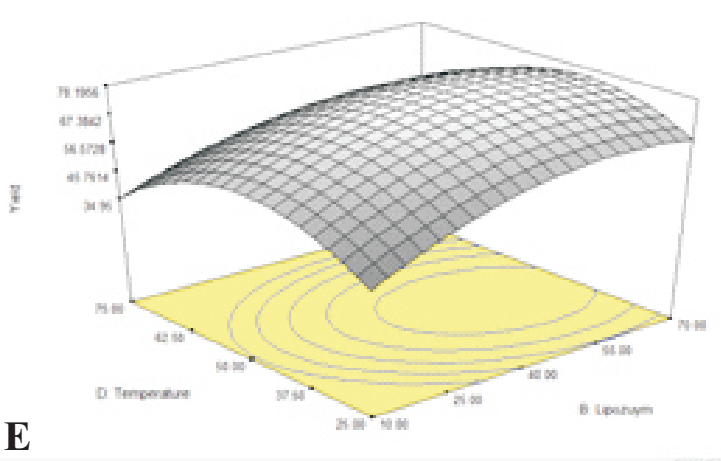

levels of lipozymeconcentration the biodiesel yield did not increase. However at optimum lipozyme concentration, a maximum biodiesel yield was obtained, but the yield decreased with increase and decrease in temperature. Figure 1 (f) shows the 3D plot for the interaction of incubation time and temperature on biodiesel yield.

Table 3 shows some fuel properties of biodiesel produced. The specific gravity was 0.91 and refractive index was $1.41 \pm 0.01$. The biodiesel had the viscosity of 14.1 , the calorific value of $38.0 \pm 0.10$ $\mathrm{mJ} / \mathrm{kg}$ and cetane number of 53.9. The flash point and cloud point were $150^{\circ} \mathrm{C}$ and $77^{\circ} \mathrm{C}$ respectively. The iodine value was $101.0 \pm 0.53 \mathrm{gI} / 100$ ? g, acid value was $0.57 \pm 0.01 \mathrm{mg} \mathrm{KOH} / \mathrm{g}$ and saponification value was $180 \pm 0.25 \mathrm{mg} \mathrm{KOH} / \mathrm{g}$ respectively.
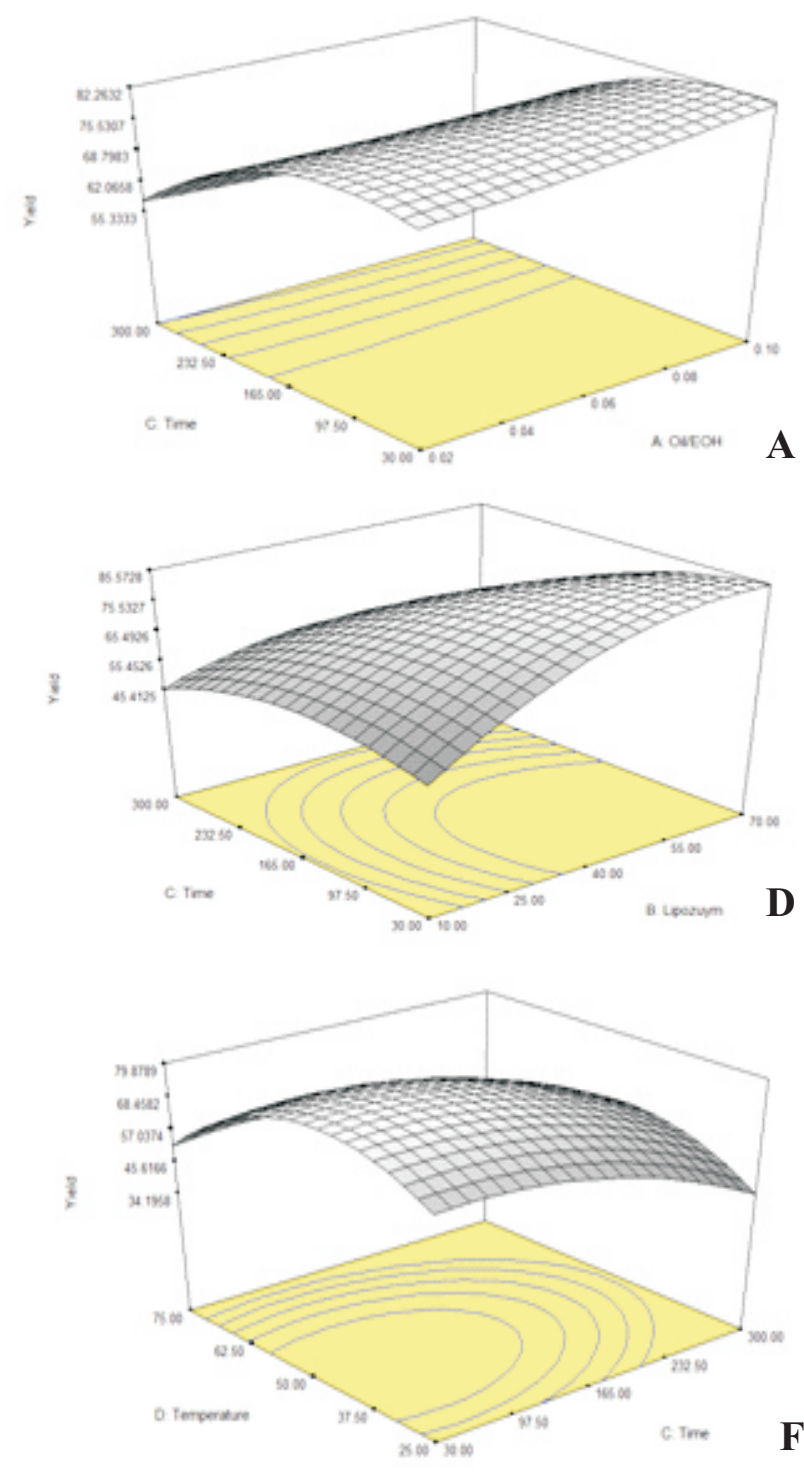
Figure 1: A three dimensional response surface plot of (a) the effect of oil: ethanol ratio and lipozyme concentration (b) the effect of oil: ethanol ratio and incubation time (c) the effect of oil: ethanol ratio and temperature (d) the effect of lipozyme concentration and incubation time (e) the effect of lipozyme concentration and temperature (f) the effect incubation time and temperature on biodiesel yield

Table 3. Physicochemical properties of castor oil seed biodiesel

\begin{tabular}{|c|c|c|c|}
\hline Properties & $\begin{array}{l}\text { Castor seed } \\
\text { ethyl ester }\end{array}$ & Diesel & ASTM D6751 \\
\hline Biodiesel yield (\%) & 93.0 & - & - \\
\hline Specific gravity & 0.91 & & - \\
\hline Refractive index & $1.41 \pm 0.01$ & & \\
\hline Viscosity at $40^{\circ} \mathrm{C}$ (Cs & 14.1 & 2.8 & $1.9-6$ \\
\hline Calorific value $(\mathrm{MJ} / \mathrm{kg})$ & $38.0 \pm 0.10$ & 45 & \\
\hline Cetane number & 53.9 & 52 & \\
\hline Flash point ${ }^{0} \mathrm{C}$ & 150 & & 93 minimum \\
\hline Cloud point ${ }^{\circ} \mathrm{C}$ & 7 & -12 & \\
\hline Iodine value $\mathrm{g} \mathrm{I}_{2} / 100 ? \mathrm{~g}$ & $101 \pm 0.53$ & & \\
\hline Acid value $(\mathrm{mg} \mathrm{KOH} / \mathrm{g})$ & $0.57 \pm 0.01$ & - & $0 / 5$ maximum \\
\hline Saponification value $(\mathrm{mg} \mathrm{KOH} / \mathrm{g}$ ) & $180 \pm 0.25$ & & \\
\hline
\end{tabular}

\section{Discussion}

In each of the three dimensional plots, the interaction effect of the two parameters was plotted while the third and fourth parameters were fixed at the medium values. The decrease in biodiesel yield at higher oil ethanol ratio could be due to separation problem resulting from excessive ethanol, or in activation of the enzyme by ethanol (Molla and Nigus, 2014). The decrease in biodiesel yield at high lipozyme concentration and oil ethanol ratio could be that, in the presence of a high amount of lipase because the enzyme active site cannot be exposed to the substrates and many molecules of the enzyme aggregate together and thus results in low biodiesel yield (Liou et al., 1998). The elliptical nature of the 3D plots shows the significance of the interactions of variables on biodiesel yield (Samukawa et al., 2000).Bello and Makanju (2011) used ethanol; oil molar ratio of 6 to 1 and obtained the biodiesel yield of $92 \%$ after 3 hours of stirring from castor oil.

The analysis of variance for the quadratic model revealed that lipozyme concentration, temperature, incubation time with their quadratic coefficients were the significant factors in biodiesel production. The value of the regression coefficient indicates that the quadratic model was able to predict almost $92.39 \%$ of the total variance of the system. The model F-value of 13.01 implies the model is significant and indicates that only a $0.01 \%$ chance that a "model F-value" this large could occur due to noise.The optimized condition for biodiesel production were oil/ethanol ratio (1:7.14), $(1.2 \mathrm{ml})$, lipozyme concentration (40 $\mathrm{U}$ ) incubation time of (165 min) and temperature $50^{\circ} \mathrm{C}$.
The high viscosity of the fuel reduces the atomization but this issue can be handled with the use of blends with petro-diesel (Deep et al., 2017).

The result shows the less likelihood of the biodiesel produced to ignite accidentally and could be safely handled for storage owing to its high flash point. The low cloud point helps in keeping the biodiesel in liquid condition which makes transportation easier. The lower calorific value could be attributed to the presence of chemically bound oxygen in the fatty acid chains (Srivastava and Prasad, 2000). Aldo et al. (2003) reported the calorific value of $30.4 \mathrm{mJkg}^{-1}$ in castor oil biodiesel.The molecular weight, fatty acid chain length, degree of unsaturation and degree of conjugation determine the refractive index of biodiesel (Sadrolhossein et al.,2011).

\section{Conclusion}

The analysis of variance for the quadratic model revealed that lipozyme concentration, oil methanol ratio, temperature and incubation time are the significant factors in biodiesel production from castor oil. The properties of the biodiesel produced were largely in conformity with ASTM D6751standards

\section{Acknowledgement}

The authors would like to thank the technical staff of the Department of Biochemistry and Chemical Engineering Ahmadu Bello University Zaria

\section{References}

Abdullah, A. Z., Salamatinia, B. Mootabadi, H. and Bhatia, S. (2009). Current status and policies on biodiesel industry in Malaysia as the world's leading producer of 
palm oil. Energy Policy. 5440-5448

Aldo, O., Temu, A. K. Ogwok, P. and Ntalikwa, J.W. (2012). Physicochemical Properties of Biodiesel from Jatropha and Castor Oils. Int. J. of Renew. Energy Research .2(1): 379-384

American Society for Testing and Materials (2000). Reapproved. Standard test methods for flash point by Pensky-Martens closed up tester. D 93. ASTM.

American Society for Testing and Materials (2000). Reapproved. Standard test method for cloud point of petroleum products. D 2500. ASTM,

AOAC International (2000) Official Methods of Analysis of AOAC International 17th $\mathrm{Ed}$ (Gaithersburg, MD.

Ashish, K., Naveen, K. Hasan, M. M. Rajeev, C. Arshad, N. S. and Zahid, A. K. (2010). Production of biodiesel from Thumba oil: Optimization of Process Parameters.Iranica J. Energ. \&Environ., 1 (4): 352358

Bello, E.I. and Makanju, A. (2011). Production, Characterization and Evaluation of Castor oil Biodiesel as Alternative Fuel for Diesel Engines. J. of Energ. Tr. in Eng. and Appl. Sci. 2(3): 525-530

Chin, L.H. Hameed, B.H. and Ahmad, A.L (2009). Process optimization for biodiesel production from waste cooking palm oil (Elaeisguineensis) using response surface methodology," Energ\& Fuels, 23 (2): 1040-1044

Deep, A., Sandhu, S. S. and Chande, C. (2017). Optimization of Reaction Parameters of Transesterification for Castor Oil. J. of Scien. \& Ind. Research. 76; 115-118

Gerpen, J.V (2005). Biodiesel processing and production. Fue I Proces s Technol.86(10):1097-1107

Giovanilton, F. S.,Fernando, L. C. and Andrea, L.O. F. (2011). Application of response surface methodology for optimization of biodiesel production by transesterification of soybean oil with ethanol. Fuel Process Technol. 92(3); 407-413

Koh, M.Y. and Mohd, G. T.I (2011). A review of biodiesel production from Jatropha oil. Renew. Sustain. Energ. Rev. 15: 2240-2251

Krisnangkura, K. (1989). A simple method for estimation of cetane index of vegetable oil methyl esters,.J. Am. Oil Chem. Soc. 63(4): 552-553.

Kumari, A, Mahapatra, P. Garlapati,V. K, and Banerjee, R. (2009). Enzymatic transesterification of Jatropha oil. Biotechnol. Biofuel, 2 (1):1-7.

Liou, Y. Marangoni, A. and Yada, R. (1998). Aggregation behaviour of Candida rugosa lipase. Food Research. Int, 31:243-248.

Molla, A. and Nigus, G. (2014). Synthesis and characterization of biodiesel from castor bean as alternative fuel for diesel engine. Am. J. of Energ. Eng. 2(1):1-15

Sadrolhosseini, A. R., Moksin, M, Nang, H. L. L, Norozi, M, Yunus, M. M. W and Zakaria, A. (2011). Physical properties of normal grade biodiesel and winter grade biodiesel, Int. J. Molecul. Scie.12. 4: 2100-2111

Samukawa, T., Kaieda, M. Matsumoto, T. Ban, K. Kondo, A. Shimada, Y. Noda, H. and Fukuda, H. (2000). Pretreatment of immobilized Candida Antarctica lipase for biodiesel fuel production from plant oil. J. Biosci. Bioeng. 90(2):180-183

Srivastava, A. and Prasad, R. (2000). Renew . Sustain. Energ. Rev. 4:111-133

Vicente, G., Coteron, A., Martinez, M. and Aracil, J. (1998). Application of factorial design of experiments and response surface methodology to optimize biodiesel production.Ind. Crops Prod. 8; 29-35

Warabi, Y., Kusdiana, D and Saka, S. (2004). Reactivity of triglycerides and fatty acids of rapeseed oil in supercritical alcohols. Bioresour. Technol.91:283-287 